\title{
Diversity of Scleria (Cyperaceae) in Santa Catarina, Brazil'
}

\author{
Regina Affonso ${ }^{2}$, Ana Zanin ${ }^{2,4}$ Neil Alistair Brummitt ${ }^{3} \&$ Ana Claudia Araújo ${ }^{3}$
}

\begin{abstract}
Scleria is the fifth largest genus of Cyperaceae, and the third most diverse genus of Cyperaceae in Brazil. In Santa Catarina the floristic account of Cyperaceae is in need of updating, particularly as the Atlantic forest, home to many species of Scleria, is one of the most threatened environments worldwide. Scleria is thus a leading candidate for an updated floristic account, particularly so as to identify the conservation status of its species within the remaining natural vegetation. The survey has confirmed thirteen taxa including a new subspecies, S. georgiana ssp. australis, here described. Scleria sellowiana is lectotypified here. A species identification key, morphological descriptions, geographic distributions, global conservation status according to IUCN Red List criteria, habitats, phenological aspects, taxonomic notes and illustrations are provided for each species. Key words. Conservation status, lectotypification, new subspecies, South America, taxonomy.
\end{abstract}

\section{Introduction}

Scleria P.J. Berg. is the fifth largest genus of Cyperaceae (Heywood et al. 2007), comprising 220-250 species (Goetghebeur 1998; Camelbeke et al. 2003) worldwide; it is the third most diverse genus of Cyperaceae in Brazil after Rhynchospora Vahl (147 species) and Cyperus L. (101 species), with 73 species recorded by Alves et al. (2014). Although Cyperaceae occur preferentially in the tropics, in open and wet or flooded environments, species of Scleria mostly prefer forests with diffused light, but also occur in relatively dry environments.

Important taxonomic and floristic studies addressing the family, and treating the genus Scleria in different areas of the Americas, include Core (1936), Adams (1994), Strong (1994, 2007), Kearns et al. (1998), Strong \& Acevedo-Rodríguez (2005), Guaglianone et al. (2008) and Alves et al. (2014). In Brazil, however, few recent regional floras focusing on this genus are known (Muniz \& Shepherd 1987; Araújo 2009). Barros (1960) reported 15 species from Santa Catarina, based on collections made up until the late 1950s. Since then not only has the vegetation in southern Brazil changed, but species circumscription and nomenclature have also changed. Species new to science have been described (Strong 1994, 2007; Araújo \& Brummitt 2011), prompting the need for an updated account of Scleria in Santa Catarina, particularly in the light of the effort to produce a complete inventory of the plant species diversity of Brazil.

This study aims to understand the species diversity of Scleria in Santa Catarina, updating the species circumscriptions and nomenclature, enabling their identification and documenting their conservation status worldwide. An identification key, morphological descriptions and general comments on distribution, habitat, ecology and phenology, as well as illustrations, are also presented.

\section{Material and Methods}

This investigation was based on primary taxonomic literature and the study of 800 specimens from: BM, CRI, FLOR, FURB, HBR, ICN, JOI, K, MBM, NY (pro part), PACA and RB; collections from MO, NY (pro part) and $\mathrm{P}$ were accessed online. Herbarium acronyms follow Thiers (continously updated). The sign "!" after the herbarium abbreviation indicates that the type sheet or image has been seen.

\footnotetext{
${ }^{1}$ This study was funded through a scholarship from the Coordenação de Aperfeiçoamento de Pessoal de Nivel Superior (CAPES), and the visit of the last author to the herbarium of the Botanischer Garten und Botanisches Museum Berlin-Dahlem was funded by Synthesys (European Union-funded Integrated Activities grant).

${ }^{2}$ University of Santa Catarina, Laboratory of Vascular Plant Systematics, Department of Botany, Campus Trindade, Florianópolis, SC, 88040-900, Brazil.

${ }^{3}$ Natural History Museum, Department of Life Sciences, Cromwell Road, South Kensington, London, SW7 5BD, UK.

${ }^{4}$ Author for correspondence: anazannin@gmail.com
} 
Field expeditions were conducted between 2010 and 2011, the top set of vouchers was deposited at FLOR and duplicates sent to: BM, COL, CRI, FURB, GUA, HB, HBR, HUEFS, ICN, K, MBM, MO, NY, P, PACA, R, RB, SI, SP, depending on the availability of each species. A selected specimen is cited bellow the description; the remaining material is listed in the Annex as "index of collections studied".

Species descriptions are based on authors' collections, while the genus description is based on the species found in the area, following Beentje (2010) and Camelbeke et al. (2003). Accepted names follow WCSP (2014), and their respective synonyms are found in Alves et al. (2014). Only synonyms lately used in the herbaria investigated are cited.

Preliminary IUCN categories were established after applying the ArcView GIS 3.3 Conservation Assessment Tool extension (Willis et al. 2003), with values for "extent of occurrence" (EOO) and "area of occupancy" (AOO) calculated in $\mathrm{km}^{2}$ (IUCN 2012). The results were analysed and final IUCN Red List ratings produced following the guidelines of IUCN (2014).

\section{Results and Discussion}

Scleria is represented in Santa Catarina by 13 confirmed taxa, one of which is a new subspecies. They are found on sandbanks, in coastal fields, highlands and in Atlantic forest occupying different environments, especially forest edges, transitional vegetation between forest and grassland, wet grasslands and wetlands. The highest concentration of species and individuals was recorded in the east of the state, especially in the coastal areas, and in the southern and northern plateaux.

Eight taxa listed for Santa Catarina have a South Amercian distribution, Scleria sellowiana Kunth and S. ulleana Boeck. being microthermic (Burkart 1975). Scleria microcarpa Nees ex Kunth and $S$. secans (L.) Urban are well distributed across the whole American continent, while $S$. distans Poir., S. gaertneri Raddi and S. latifolia Sw. are pantropical, extending into subtropical areas. However, four taxa are confirmed as endemic to
Brazil: S. filiculmis Boeck., S. georgiana Core ssp. australis A.C. Araujo, S. uleana and S. variegata (Nees) Steud., the first being microthermic and the latter being macrothermic with its austral distribution limit in Santa Catarina; similarly, S. leptostachya Kunth also has its southernmost distribution in this state.

Scleria filiculmis and S. georgiana subsp. australis have been assessed as Vulnerable under IUCN criteria, both being endemic to southern Brazil; the remaning taxa are assessed as Least Concern. Scleria balansae Maury, S. hirtella Sw., S. myricocarpa Kunth and S. pauciflora Muhl. ex Willd. cited by Barros (1960) were all misidentifications, and have not been confirmed in Santa Catarina. This paper presents as a taxonomic novelty a new subspecies endemic to Santa Catarina, and proposes a lectotype for $S$. sellowiana.

Scleria P. J. Bergius, Kongl.Vetensk. Acad. Handl. 26: 142, pl. 4-5. 1765. Type species: Scleria flagellum-nigrorum P. J. Bergius, nom. cons.

Perennial herbs, erect or climbing, rhizome slender or tuberous. Culm triangular, generally not branching (except $S$. secans). Leaves developed, sheath winged or not, ligule present or absent; contraligule obtuse, triangular or truncate, membranous appendage present or not; leaf blade plicate, linear or lanceolate, apex acute, attenuated or pseudopremorse, margin smooth, scabrous or pilose. Inflorescense a paniculodium, fasciculate spike or just a fascicle, bisexual; bracts present or not. Spikelet unisexual, androgynous or subandrogynous; staminate or pistillate glumes lanceolate to ellipsoid, brown, ferruginous to vinaceous, apex apiculate, mucronate or attenuate. Achene globose to trigonous-globose, ovoid or ellipsoid, smooth or ornamented, white to vinaceous, trichomes present or not, base muticous or stipitate, entire or attenuate, pores at the base present or not; stylobase usually absent, if present deciduous. Hypogynium when present lobed, cupuliform, membranous, cartilaginous or papillose, margin various; or developed as tubercles at the base.

\section{Key to species of Scleria from Santa Catarina state}

1. Climbing herbs.

2. Ligule present. Plant branching. Leaf margins razor-like 10. Scleria secans

2'. Ligule absent. Plant not branching. Leaf margins scabrous, not razor-like. 
3. Hypogynium absent. Sheath not winged. Achene verruculose.

13. Scleria variegata

3'. Hypogynium present. Sheath winged. Achene smooth.

12. Scleria uleana

1'. Erect herbs

4. Contraligule with membranous appendage; achene reticulate-verrucose

6. Scleria leptostachya

4'. Contraligule without membranous appendage; achene smooth, reticulate or rugose.

5. Hypogynium absent.

6. Achene ovoid, slightly sulcate vertically towards the base, pores present

4. Scleria georgiana ssp. australis

6'. Achene globose, smooth, not sulcate, pores absent

1. Scleria distans

5'. Hypogynium present

7. Papillose tubercles present, achene rugose or reticulate.

8. Achene ellipsoid with a basal three-lobed disk with a thickened margin, supporting and compressing the tubercles. 2. Scleria filiculmis

8'. Achene trigonous-globose, basal disk absent.

11. Scleria sellowiana

7'. Tubercles at the base of the achene absent, achene smooth or rugose.

9. Contraligule lanceolate. Hypogynium cupuliform, margins ciliate.

7. Scleria microcarpa

9'. Contraligule triangular or obtuse. Hypogynium three-lobed, margins entire or laciniate.

10. Hypogynium somewhat corky, margin entire. Leaf blade $0.5-0.7 \mathrm{~cm}$ wide...

3. Scleria gaertneri

10'. Hypogynium membranous, margin laciniate. Leaf blade $1-5 \mathrm{~cm}$ wide.

11. Achene smooth, vinaceous, black (rarely white) .......5. Scleria latifolia 11'. Achene rugose, white.

12. Herbs up to $70 \mathrm{~cm}$ tall. Spikelets up to 70 . Achene rugose 9. Scleria plusiophylla

12'. Herbs taller, from $80 \mathrm{~cm}$ tall. Spikelets 100-200. Achene tuberculate 8. Scleria panicoides

1. Scleria distans Poir., Encycl. 7: 4. 1806. TYPE: Porto Rico, A. P. Ledru 110 p.p. (lectotype P; isolectotype P). Designated by Raynal (1976).

Fig. 1a-d

Perennial herb, erect, 13-47(-72) cm tall, rhizomatous. Culm 1-2 mm wide, not branching, angle smooth. Sheath $1-4(-5.5) \mathrm{cm}$ long, not winged; ligule absent; contraligule $1-3 \mathrm{~mm}$ long, truncate, pilose, membranous appendage absent; leaf blade 3-18 $\times 0.2-0.3 \mathrm{~cm}$, linear, apex acute, margin smooth. Inflorescence a simple fasciculate spike, terminal, $3-10 \times 0.5-0.8 \mathrm{~cm}$, fascicles (3)4-7(10), disposed along the culm; bracts absent. Spikelets androgynous, sessile, staminate glume 2-4 × 1-2 mm, pistilate glume 3-5 × 1.5-3.0 mm. Achene 1.5-2.0 × 1.0-1.5 mm, globose, smooth, glabrous, white (brown if immature), base stipitate, entire, pores absent, basal disk absent; stylobase absent. Hypogynium absent.

Scleria distans is a pantropical species (Camelbeke et al. 2003); in Brazil it is recorded in Amazonian and Atlantic forests, Cerrado and Pampa (Alves et al. 2014). In Santa Catarina it is the most common species, distributed throughout coastal regions, from the Vale do Itajaí to the South, highland plateaux and along the far west of the State in open and damp environments such as marshes, wet grasslands, forest edges and disturbed vegetation, as well as in degraded environments such as lawns and roadsides, in sandy, clayey or stony soil. This species is frequently identified as $S$. hirtella Sw., which differs from $S$. distans by a caespitose habit and having pores at the base of the achene (Camelbeke et al. 2003; Araújo 2009). Both species have a disjunct distribution between the Neotropics and Africa (Araújo 2009), but in the Americas while $S$. distans is widely distributed including colder regions such as southern South America in Argentina and southern Brazil, S. hirtella is restricted to tropical areas (Camebeke et al. 2003). It flowers and fruits all year. 
IUCN Red List category - LEAST CONCERN (LC). A common, widely distributed species, including within protected areas, with an EOO of more than $40,000,000 \mathrm{~km}^{2}$ and an AOO of more than $35,000,000 \mathrm{~km}^{2}$.

Selected specimen: BRAZIL. SANTA CATARINA: Laguna, 7.XII.2010, fl, fr, Affonso \& Zanin 134 (BM, FLOR, K).

2. Scleria filiculmis Boeck., Allg. Bot. Z. Syst. 2: 158. 1896. TYPE: Brazil, Santa Catarina, Serra Geral, E. H. G. Ule 1939 (lectotype K!). Designated by Affonso et al. (2013) Fig.1e-h

Perennial herb, erect, 25-46 cm tall, rhizomatous. Culm 1.0-2.5 mm wide, 1-2, not branching, angle smooth, pilose or not. Sheath $2.5-10.0 \mathrm{~cm}$ long, not winged; ligule absent; contraligule $0.5-1 \mathrm{~mm}$ long, obtuse, pilose, membranous appendage absent; leaf blade 8-25(-36) × 0.15-0.40 cm, linear, apex acute, margin smooth. Inflorescence a fascicle, terminal or terminal and axillary, $0.5-1.8 \times 0.5-1.5 \mathrm{~cm}$, 3-6 spiketes in the fascicle; bracts $1.5-5.5$ $\times 0.10-0.25 \mathrm{~cm}$. Spikelets subandrogynous, pedicellate, staminate glume $4-7 \times 2-3 \mathrm{~mm}$, pistillate glume 3-4 × 2-4 mm. Achene 2.0-3.3 $\times 2.0-2.3 \mathrm{~mm}$, ellipsoid, reticulate, glabrous, white, base muticous, basal disk three-lobed, the margin thickened, supporting and compressing the tubercles, pores absent; stylobase absent. Hypogynium bearing six papillose tubercles at the base of the achene.

Scleria filiculmis is endemic to Brazil (Guaglianone et al. 2008), recorded from the Atlantic forest (Alves et al. 2014) in the highlands of southern Brazil. Although Core (1936) and Ferreira \& Eggers (2008) described this species as "lacking a hypogynium", detailed study of the type material revealed a hypogynium with tubercles. Scleria colorata (an accepted species) is not confirmed in Santa Catarina; the collection R. Reitz \& R.M. Klein 10067 (HBR) identified as such by Barros in 1963 is actually S. filiculmis. The inflorescence of $S$. filiculmis resembles $S$. georgiana Core ssp. australis and S. sellowiana Kunth, differing by the presence and/or shape of the hypogynium, dimension of the leaf blades and the achene surface. Scleria filiculmis has been misidentified as $S$. balansae Maury, from which differs by the achene and hypogynium morphology. The latter is confirmed from Paraná but not yet known from Santa Catarina.
IUCN Red List category - VULNERABLE (VU B1ab(iii)+B2ab(iii)+D2). The Atlantic Forest is one of the most threatened habitats in the world (Brooks et al. 1999; Myers et al. 2000; Fonseca et al. 2003) and the restricted distribution of $S$. filiculmis in the Atlantic forest of the southern Brazilian highlands is concerning, particularly when much of this area has been used for pine plantations, cattle ranching and agriculture. The species has so far been found only in the localities of Campo Alegre and Serra Geral in Santa Catarina and Vacaria in Rio Grande do Sul, none of which is protected. The specimen from the vicinity of Vacaria was collected in 2006 by the last author in disturbed Atlantic forest and is the first record for the species outside the state of Santa Catarina. However, the specimen collected in Serra Geral in 1891 (Ule 1939) - the type collection - has no more detailed locality than this. Due to the lack of detail for the type locality it is impossible to be sure of the exact size of the extent of occurrence; however, we can be sure that $S$. filiculmis does not exceed the threshold of $20,000 \mathrm{~km}^{2}$ for Vulnerable under Criterion B and also has a restricted Area of Occupancy of less than $20 \mathrm{~km}^{2}$ if using a cell size of $2 \times 2 \mathrm{~km}$ (IUCN 2014). A further locality from Guaratuba in Paraná remains to be confirmed. Threats to this species are from continuing clearance of the native vegetation for livestock and arable agriculture, and for forestry. Recent surveys in known localities have failed to record the species; further surveys in its three known localities and the surrounding areas need to be undertaken to confirm its present status and the number of mature individuals occurring in each location; additional research may reveal that this species should be reassessed as Endangered.

Examined specimen: BRAZIL. SANTA CATARINA: Campo Alegre, Morro do Campo Alegre, 7.X.1960, fl, fr, Reitz \& Klein 10067 (HBR).

3. Scleria gaertneri Raddi, Accad. Lucchese Sci., Lett. ed. Arti 2: 331. 1823. TYPE: Brazil, Rio de Janeiro, G. Raddi s.n. (holotype PI image!).

Scleria melaleuca Rchb. ex Schltdl. \& Cham., Linnaea 6(1): 29. 1831. TYPE: Suriname, $C$. Weigelt s.n. (holotype G!; isotypes F!, G!, HAL!).

Fig. 1i-1

Perennial herb, erect, (30)-60-130 cm tall, caespitose-rhizomatous. Culm 1-5 mm wide, not branching, angle scabrous. Sheath $3.5-7.0 \mathrm{~cm}$ long, winged; wings $1-2 \mathrm{~mm}$ wide; ligule absent; 
contraligule 2-6 $\times 1-5 \mathrm{~mm}$, triangular (rare obtuse), glabrous, membranous appendage absent; leaf blade $14-25 \times 0.5-0.7 \mathrm{~cm}$, linear, apex acute or pseudopremorse, margin scabrous. Inflorescence a paniculodium, elongated, terminal and axillary, $2.5-8.0 \times 0.5-2.0 \mathrm{~cm}$; bracts $6-11 \times 0.3-0.5 \mathrm{~cm}$. Spikelets subandrogynous or staminate, sessile and pedicellate, respectively, staminate glume 3-4 × 1.0-1.5 mm, pistillate glume 2-4 × 1.0-2.5 mm. Achene 1.8-2.3 × 1.5-2.0 mm, depressed-globose, smooth, usually glabrous, occasionally pilose, white, base muticous, pores absent, basal disk absent; stylobase absent. Hypogynium three-lobed, somewhat corky, lobe-margin entire, smooth.

Scleria gaertneri is a pantropical species (Camelbecke et al. 2003, recorded as S. melaleuca Rchb. ex Schltdl. \& Cham.); in Brazil it has been recorded in all biomes (Alves et al. 2014). In this State it occurs from the northern coast to as far as the Island of Santa Catarina, including inland areas of the Vale do Itajaí on sunnier edges of humid forests, or less often occupying wet grassland, the edges of sandbank vegetation and disturbed forest remnants. In herbaria it is usually identifyed as $S$. pterota C. Presl (nomen nudum) or S. melaleuca (synonym, Longhi-Wagner et al. 2010). It differs from the other species by the elongated paniculodium, by its smooth and globose achenes and by the corky hypogynium, trilobed and with an entire margin. It flowers and fruits equally all year long.

IUCN Red List category - LEAST CONCERN (LC). A common, widely distributed species, also found in protected areas, with an EOO of more than $15,000,000 \mathrm{~km}^{2}$ and an AOO of more than $17,000,000 \mathrm{~km}^{2}$.

Selected specimen: BRAZIL. SANTA CATARINA: Araquari, 16.III.2011, fl, fr, Affonso \& Zanin 198 (FLOR, FURB, K).

4. Scleria georgiana Core ssp. australis A.C. Araújo, ssp. nov. TYPE: Brazil, Santa Catarina, Florianópolis, Jurerê, 14 Jan.1965, fl, fr, R. $M$. Klein \& A. Bresolin 6180 (holotype FLOR!).

Fig. 1m-p

Diagnosis: Rhizome slender, culms isolated, contraligule truncate, achenes slightly sulcate vertically towards the base; it differs from the North American taxon which shows a nodulose rhizome, culms in tufts, the contraligule is absent, and the achene ribbed with three ridges (Ball et al. 2014).

Perennial herb, erect, 23-52 cm tall, rhizomatous. Culm 0.8-1.2 mm wide, not branching, angle smooth. Sheath 3-12 cm long, not winged; ligule absent; contraligule $0.8-1.2 \mathrm{~mm}$, truncate, glabrous, membranous appendage absent; leaf blade $3-23 \times 0.1-0.3 \mathrm{~cm}$, linear, apex acute, margin smooth. Inflorescence a fascicle, terminal, $0.5-1.0 \times 0.5-1.5 \mathrm{~cm}$, fascicle with $3-6$ spikelets; bracts $1-6 \times 0.1-0.2 \mathrm{~cm}$. Spikelets androgynous and subandrogynous, sessile or pedicellate, staminate glume $3-4 \times 1.5-2.5 \mathrm{~mm}$, pistillate glume 2-3 $\times$ 2-3 mm. Achene 2.0-3.3 × 2.0-2.3 mm, ovoid, smooth, slightly sulcate vertically toward to the base, glabrous, white, base stipitate, attenuated, pores present, basal disk absent; stylobase absent. Hypogynium absent.

Scleria georgiana ssp. australis has been found only in Santa Catarina state, although it has been suggested to also occur in Paraguay (Barros 1960); however, this has never been confirmed and no specimens are cited with which this can be checked. The species is recorded from scarce populations near the coastline, in the Parque Estadual do Maciambú (Palhoça), and formerly in Jurerê beach (Florianópolis) and in Sombrio, the latter being the southern known limit for the species; it is possibly restricted to the Parque Estadual do Maciambú. This taxon inhabits moist sandbanks and sandy marshes. Until very recently both taxa were recognized as one, performing a rather odd disjunction between the neotropical North and Central America and the subtropical region of Southern South America. A careful morphological and ecological study proved to be essential in recognizing this new taxon. Scleria georgiana ssp. australis differs from others described here based on the achene shape, surface and ornamentation, which has pores present at the base. It was collected with flowers and fruits in January, September and October.

IUCN Red List category - VULNERABLE (VU D2). Discounting the supposed presence of this subspecies in Paraguay, which has been suggested but in the absence of any evidence and never confirmed, it is currently only known from coastal marshland near the Parque Estadual do Maciambú. Other localities in Florianópolis and in Sombrio are no longer thought to be extant. Although the State Park of Maciambú is in good condition, the coastal marshland does not come under this protection, and although much marshland remains outside the park there is clear evidence of agriculture and residential development in the area. Due to the uncertainty surrounding the 


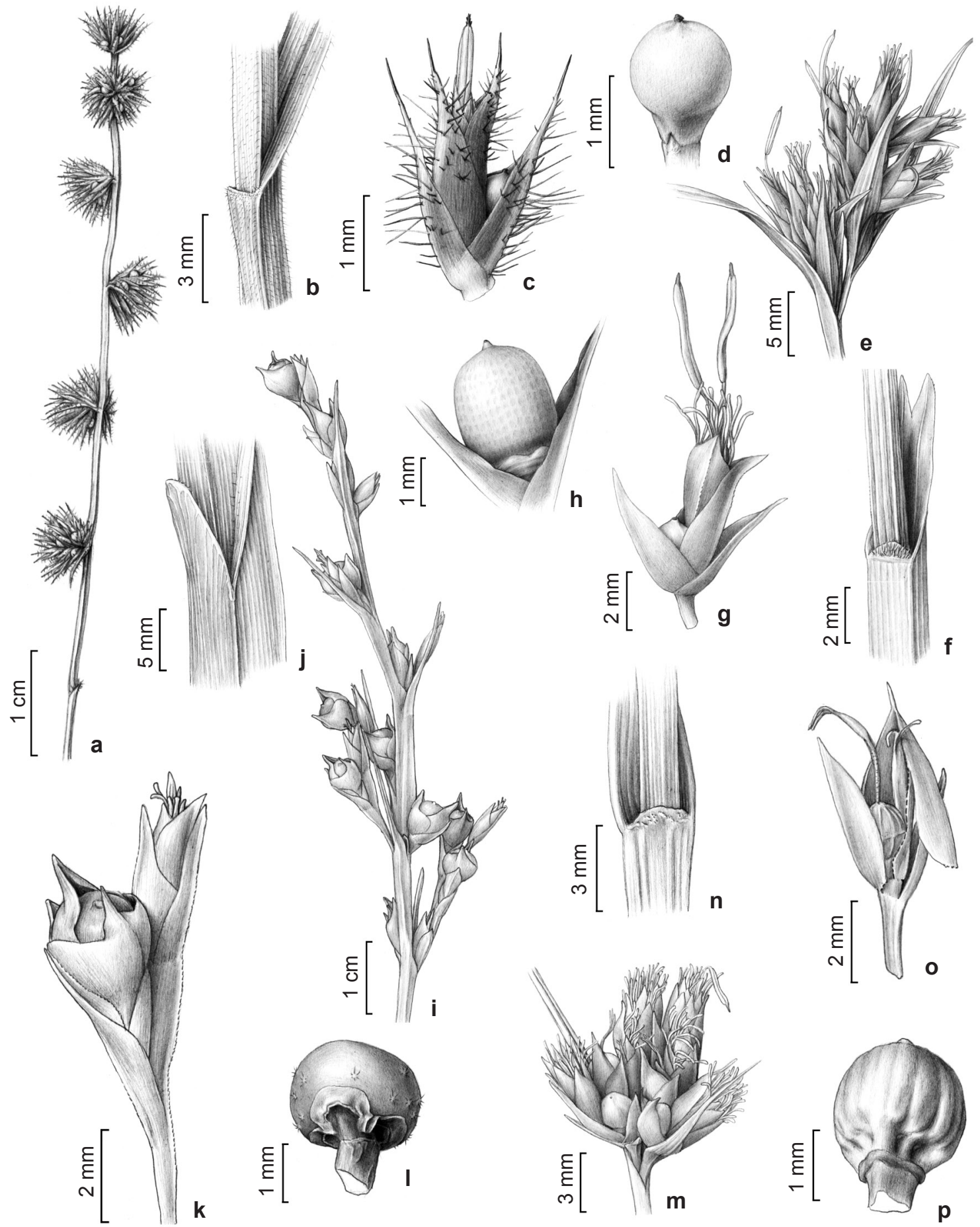

Figure 1 - a-d. Scleria distans (a-c. R. Affonso et al. 108, d. R. Affonso \& A. Zanin 134) - a. inflorescence; b. contraligule truncate; c. spikelet bearing achene at the base, d. achene. e-h. Scleria filiculmis (R. Reitz \& R.M. Klein $10067)$ - e. partial inflorescence; f. contraligule obtuse; g. spikelet bearing achene at the base; $h$. achene reticulate; hypogynium showing basal disc compressing the tubercles. i-1. Scleria gaertneri (R. Affonso \& A. Zanin 198) - i. partial inflorescence; j. contraligule triangular; $\mathrm{k}$. spikelets, the basal one bearing an achene; 1 . achene pilose; hypogynium trilobed, margin entire. m-p. Scleria georgiana Core ssp. australis (R.M. Klein \& A. Bresolin 6180) - m. partial inflorescence; $\mathrm{n}$. contraligule truncate; o. spikelet bearing an achene; $\mathrm{p}$. achene vertically sulcate. 
precise localities for this subspecies, but due also to the small number of collections, few remaining localities, the restricted area of occupancy and the continuing development of the coastal marshland area presenting a probable threat to this subspecies, the most appropriate IUCN category is Vulnerable under Criterion D2.

Selected specimen: BRAZIL. SANTA CATARINA: Palhoça, 16.IX.2007, fl, fr, Tavares \& Guimarães s.n. (FLOR 38973).

5. Scleria latifolia Sw., Prodr.: 18. 1788 TYPE: Jamaica, O. P. Swartz S.n. (holotype L; photo of isotype NY image!).

Fig. 2a-f

Perennial herb, erect, (52-)60-130(-250) cm tall, caespitose-rhizomatous,. Culm 5-7 mm wide, not branching, angle scabrous. Sheath (4-)6-15(-22) cm long, winged; ligule absent; contraligule 5-7 mm long, triangular, glabrescent, membranous appendage absent; leaf blade (15-)32-78 × (1.5-)2.5-5.0 cm, lanceolate, apex pseudopremorse, margin scabrous. Inflorescence a paniculodium, terminal and axillary, $(5-) 6-13 \times 2-8 \mathrm{~cm}$; bracts $5-15(-22) \times 0.5-1.5 \mathrm{~cm}$. Spikelets subandrogynous or staminate, sessile and pedicellate, respectively, staminate glume 2-4×1-2 $\mathrm{mm}$, pistillate glume $2-5 \times 1-3 \mathrm{~mm}$. Achene $3-4 \times$ 2.0-3.5 mm, globose, smooth, glabrous, black or vinaceous (rare white), base muticous, pores absent, basal disk absent; stylobase absent. Hypogynium three-lobed, membranous, margin laciniate.

Scleria latifolia is a neotropical species (Core 1936; Camelbeke et al. 2003), present in Amazon and Atlantic forests, Caatinga and Cerrado of all Brazilian regions (Alves et al. 2014). In Santa Catarina it is distributed throughout, occupying the edges of moist forests, shaded and humid environments of shrubby to tall sandbank vegetation, well adapted to anthropogenic environments such as edges of trails, roadsides and forest remnants near watercourses. Scleria latifolia has pioneer potential in degraded environments. Scleria latifolia resembles $S$. panicoides Kunth, differing by the shape, colour and ornamentation of the achene. The achene's white colour when dry turns dark violet when re-hydratated. Locally known as monkey razor (= "navalha-de-macaco", due to sharp leaf blades), bird nuts (= "baga-decurió", staple food for birds) or wild wheat (= "trigo-guarani”, eaten by Guarani people).

IUCN Red List category - LEAST CONCERN (LC). A common, widely distributed species found in protected areas, with an EOO of more than $17,000,000 \mathrm{~km}^{2}$ and an AOO of more than $16,000,000 \mathrm{~km}^{2}$.

Selected specimen: BRAZIL. SANTA CATARINA: Itajaí, 16.III.2011, fl, fr, Affonso \& Zanin 191 (FLOR, K).

6. Scleria leptostachya Kunth, Enum. P1. 2: 354. 1837. TYPE: Brazil, F. Sellow s.n. (holotype B; isotype $\mathrm{K} !)$.

Scleria catharinensis Boeck., Allg. Bot. Z. Syst. 2: 158. 1896. TYPE: Brazil, Santa Catarina, Serra Geral, Capivari, Jan. 1891, E. H. G. Ule 1923 (lectotype K!, isolectotypes CORD!, P; photo of holotype NY image!). Designated by Affonso et al. (2013).

Fig. 2g-k

Perennial herb, erect, 40-80 $\mathrm{cm}$ tall, rhizomatous. Culm 1-2 mm wide, not branching, angle pilose. Sheath $3.5-6 \mathrm{~cm}$ long, not winged; ligule absent; contraligule 1-3 mm long, obtuse, pilose, membranous appendage present; leaf blade $17-25 \times 0.3-0.5 \mathrm{~cm}$, linear, apex acute or attenuated, margin pilose. Inflorescence a spike of fascicles or a paniculodium, terminal, 4.5-9.0 × $1 \mathrm{~cm}$, fascicles 5-10, disposed along the stem, each fascicle with 2-5 spikelets; bracts absent. Spikelets androgynous, sessile or shortly pedicellate, staminate glume $3-4 \times 1.0-1.5 \mathrm{~mm}$, pistilate glume $2-3 \times 1.0-1.5 \mathrm{~mm}$. Achene $0.8-1.0$ $\times 1 \mathrm{~mm}$, trigonous-globose, reticulate-verrucose, glabrous, brown (white if imature), base stipitate, entire, pores present, basal disk absent; stylobase absent. Hypogynium absent.

Scleria leptostachya occurs in South America (Camelbeke et al. 2003); in Brazil it spreads from the northeast to the south (Alves et al. 2014). Santa Catarina is the southern limit of its occurrence where fewer records have been found, two from the coast, and three to the middle-west, those latter ones collected between 1959 and 1962. This species differs from all other species by its panicle of fascicles, lax here whereas more congested in other species, and also by its achene ornamentation, unique to this species.

A morphological comparison between the type collections of Scleria catharinensis and $S$. leptostachya, supported by the protologue of these two species, confirmed that they are the same taxon, as stated by Guaglianone et al. (2008). The species flowers and fruits in January and February.

IUCN Red List category - LEAST CONCERN (LC). A common, widely distributed species, also found in protected areas, with an EOO of more than $4,000,000 \mathrm{~km}^{2}$ and an AOO of nearly $3,000,000 \mathrm{~km}^{2}$. 
Selected specimen: BRAZIL. SANTA CATATINA: Curitibanos, 8.I.2011, fl, Affonso et al. 182 (FLOR, ICN, K, PACA).

7. Scleria microcarpa Nees ex Kunth, Enum. Pl. 2: 341. 1837. TYPE: Suriname, C. Weigelt s.n (lectotype HAL!, isolectotypes BM image!, BR image!). Designated by Affonso et al. 2013.

Fig. 21-n

Perennial herb, erect, $55-180 \mathrm{~cm}$ tall, rhizomatous. Culm 1-3 mm wide, not branching, angle smooth. Sheath $2.5-4.5 \mathrm{~cm}$ long, winged; ligule absent; contraligule 2-6 mm long, lanceolate, ciliate, membranous appendage absent; leaf blade 5-20 × 0.5-0.9 cm, linear, apex acute or attenuated, margin scabrous. Inflorescence a contracted paniculodium, terminal and axillary, $3-6 \times 1.0-1.5 \mathrm{~cm}$; bracts $5-9 \times 0.3-0.8 \mathrm{~cm}$. Spikelets subandrogynous and staminate, sessile and pedicellate, respectively, staminate glume $1.5-2.0 \times 1.0-1.5 \mathrm{~mm}$, pistillate glume $2 \times$ 1.5-2.0 mm. Achene 1.5-2 × 1.0-1.2 mm, ovoid, smooth, glabrous, white, base stipitate, entire, pores absent, basal disk absent; stylobase deciduous. Hypogynium cupuliform, cartilaginous, margin ciliate.

Scleria microcarpa is mostly neotropical (Camelbeke et al. 2003); in Brazil it is found in all biomes (Alves et al. 2014). Recorded in Santa Catarina once in 1955, at the forest's edge in Itajaí; it may no longer be found in this State. Scleria microcarpa and S. uleana Boeck. share similarities of the achene and hypogynium, but the latter is a climbing species while $S$. microcarpa is not, besides which they differ in inflorescence pattern, in the dimensions of the plant overall and of the achene, and hypogynium margins. It flowers and fruits in April.

IUCN Red List category - LEAST CONCERN (LC). A common, widely distributed species, found in protected areas, with an EOO of almost $17,000,000 \mathrm{~km}^{2}$ and an AOO of more than $18,000,000 \mathrm{~km}^{2}$.

Examined specimen: BRAZIL. SANTA CATARINA: Itajaí, Cunhas, 14.IV.1955, fl, fr, R.M. Klein 1287 (HBR).

8. Scleria panicoides Kunth, Enum. Pl. 2: 348. 1837. TYPE: Brazil, F. Sellow s.n. (lectotype HAL image!, isolectotype $\mathrm{MO}$; photo of holotype $\mathrm{F}$ image!). Designated by Affonso et al. (2013)

Fig. 20-r

Perennial herb, erect, $80-150 \mathrm{~cm}$ tall, caespitose-rhizomatous. Culm 1-5 mm wide, not branching, angle scabrous. Sheath 2.5-8.5(-26) $\mathrm{cm}$ long, green or vinaceous, winged; wings 1-5 mm wide, green; ligule absent; contraligule 2-7 mm long, obtuse or triangular, glabrescent, membranous appendage absent; leaf blade 18-38 $\times 1.5-3.5 \mathrm{~cm}$, lanceolate, apex pseudopremorse, margin scabrous. Inflorescence a paniculodium, terminal and axillary, $4-12(-15) \times 1.5-4.0 \mathrm{~cm}$, with 100-200 spikelets; involucral bracts $3-12(-15) \times$ $0.3-0.7(-1.2) \mathrm{cm}$, green. Spikelets subandrogynous or staminate, sessile or pedicellate, respectively, staminate glume $3-4 \times 2-3 \mathrm{~mm}$, pistillate glume 2-4 $\times 3-5 \mathrm{~mm}$. Achene 2-4 × 2-4 mm, globose, tuberculate, with translucent trichomes, white, base muticous, pores absent, basal disk absent; stylobase absent. Hypogynium three-lobed, membranous, lobe margin laciniate.

Scleria panicoides is a neotropical species extending to southern South America (Camelbeke et al. 2003); in Brazil it is found in the Cerrado, Atlantic forest and Pampa (Alves et al. 2014). In Santa Catarina it occurs along coastal areas and inland in highlands, forests and humid environments, especially within and on the edges of healthy forest, hillside forest and from restored mined areas. Recorded recently in coastal forest (Florianópolis) and mountain forest (Joinville), in healthy, well-developed secondary forest, indicating perhaps some tolerance to degraded environments. Besides S. latifolia, mentioned above, S. panicoides also resembles $S$. plusiphylla Steud. differing in the number and density of spikelets, and achene ornamentation. It flowers and fruits throughout the year.

IUCN Red List category - LEAST CONCERN (LC). A widely distributed species occurring within protected areas, with an EOO of more than 4,000,000 $\mathrm{km}^{2}$ and an AOO of more than 2,700,000 km².

Selected specimen: BRAZIL. SANTA CATARINA: Joinville, 17.III.2011, fl, fr, Affonso \& Zanin 204 (FLOR, GUA, K).

9. Scleria plusiophylla Steud., Syn. Pl. Glumac. 2: 172. 1855. Schizolepis foliosa Nees in C. F. P. von Martius, Fl. Bras. 2(1): 188. 1842. non Hochst. Ex Rich. (1851). TYPE: Brazil, F. Sellow s.n. (holotype B; photo of holotype NY image!). $\quad$ Fig. 3a-c

Perennial herb, erect, $30-70 \mathrm{~cm}$ tall, caespitose-rhizomatous. Culm 1-4 mm wide, not branching, angle scabrous. Sheath 2.5-6.5 $\times$ $0.2-0.5 \mathrm{~cm}$, winged; ligule absent; contraligule 2-3 $\times 2-4 \mathrm{~mm}$, obtuse or triangular, glabrous or glabrescent, membranous appendage absent; 


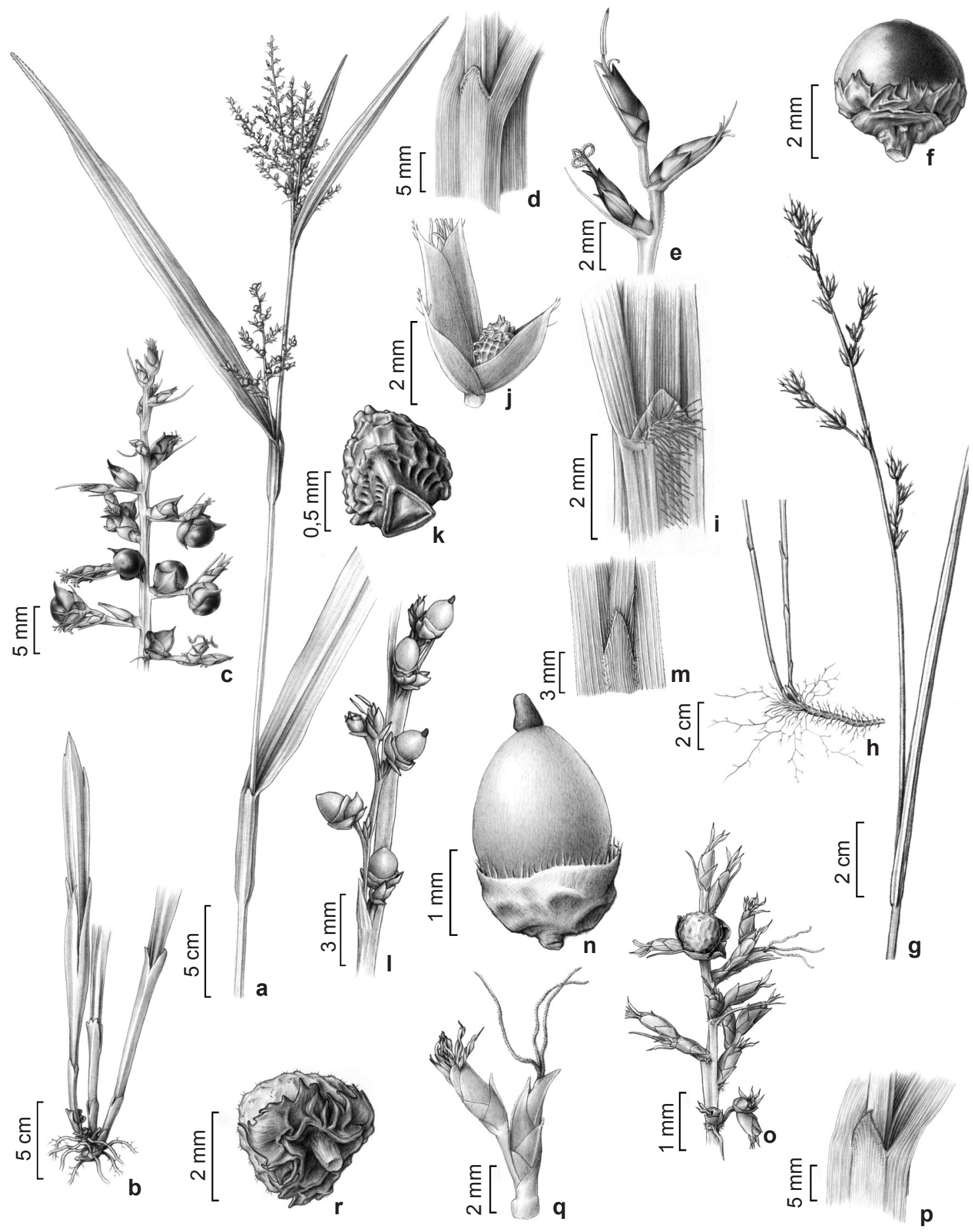

Figure 2 - a-f. Scleria latifolia ( $R$. Affonso et al. 66) - a-b. habit; c. inflorescence; d. contraligule triangular; e. spikelets; f. achene smooth; hypogynium trilobed, margin fimbriate. g-k. Scleria leptostachya (R. Affonso et al. 182) - g-h. habit; i. contraligule pilose with a membranous appendage; j. spikelet bearing an achene at the base; $\mathrm{k}$. achene reticulate-verrucose. 1-n. Scleria microcarpa (G. Hatschbach 33663) - 1. partial inflorescence; m. contraligule lanceolate; n. achene smooth; hypogynium cupuliform, margin ciliate. o-r. Scleria panicoides (R. Affonso \& A. Zanin 204 ) - o. partial inflorescence; p. contraligule triangular q. spikelets; r. achene tuberculate, hypogynium trilobed, margins fimbriate. 
leaf blade $8-28 \times 1-2 \mathrm{~cm}$, lanceolate, apex pseudopremorse, margin scabrous. Inflorescence a paniculodium, terminal or axillary, 2.5-8.0 $\times 1-3$ $\mathrm{cm}$, up to 70 spikelets; bracts $3-10 \times 0.2-0.5(-1.2)$ $\mathrm{cm}$. Spikelets subandrogynous or staminate, pedicellate and sessile, respectively, staminate glume 2-4 × 1-2 mm, pistillate glume $2-4 \times 3-5$ $\mathrm{mm}$. Achene 1.5-4.0 $\times 2-4 \mathrm{~mm}$, globose, rugose, with translucid trichomes, white, base muticous, pores absent, basal disk absent; stylobase absent. Hypogynium three-lobed, membranous, lobe margin laciniate.

Scleria plusiophylla is widely distributed in South America (Camelbeke et al. 2003); present in Atlantic rain forest and the Brazilian central savanna (Alves et al. 2014). In Santa Catarina it has been recorded in the Vale of Itajaí and the northern and southern plateaux, found in shaded environments inside moist forest. It flowers and fruits throughout the year.

IUCN Red List category - LEAST CONCERN (LC). A common, widely distributed species found within protected areas, with EOO of more than $2,800,000 \mathrm{~km}^{2}$ and an AOO of more than $2,000,000 \mathrm{~km}^{2}$.

Selected specimen: BRAZIL. SANTA CATARINA: Criciúma, 8.XII.2010, fl, fr, Affonso \& Zanin 144 (FLOR, RB).

10. Scleria secans (L.) Urb., Symb. Antill. 2(2): 169. 1900. Schoenus secans L., Syst. Nat., ed.10, 2: 865 (1759). TYPE: Jamaica, H. Sloane, Voy. Jamaica 1: t. 77, f. 1. 1707 (lectotype BM! designated by; isolectotype BM!). Camelbeke et al., (2003).

Fig. 3d-h

Perennial herbs, climbing, 2-7 $\mathrm{m}$ tall, caespitose-rhizomatous. Culm 1.5-6 mm wide, branching, angle strongly scabrous. Sheath 1.5-6.0(-11.5) cm long, winged; ligule present; contraligule 2-5 mm long, obtuse, glabrous, membranous appendage present; leaf blade (12)32$78 \times 0.2-0.5 \mathrm{~cm}$, linear, apex atenuate, margin scabrissimous. Inflorescence a paniculodium, terminal and axillary, $3-8 \times 1.5-3.5 \mathrm{~cm}$; bracts $2-12(-18) \times 0.2-0.5 \mathrm{~cm}$. Spikelets staminate and pistillate, pedicellate and sessile, respectively, staminate glume $3-5 \times 1-2 \mathrm{~mm}$, pistillate glume $2-5 \times 2-3 \mathrm{~mm}$. Achene $3-5 \times 2-3 \mathrm{~mm}$, ovoid, smooth, glabrous (rare pubescent), white, base stipitate, pores absent, basal disk absent; stylobase deciduous. Hypogynium three-lobed, cartilaginous, margin entire, smooth.
Scleria secans is a widespread neotropical species (Camelbeke et al. 2003), found in all biomes in Brazil (Alves et al. 2014). In Santa Catarina it has been recorded from the Vale do Itajaí and the northern plateau, within moist forests and at their edge. Local populations may form a thicket reaching ca. $7 \mathrm{~m}$ tall, covering trees of relatively open, disturbed forests, promoting the establishment of other shade-loving species. It is known locally as dog's razor (“capa-cão") because its leaves and culms are strongly scabrous and very sharp. It differs from all other species cited here by its branched culm and presence of a ligule. It flowers and fruits all year round.

IUCN Red List category - LEAST CONCERN (LC). A common, widely distributed species, also found within protected areas, with an EOO of more than $16,700,000 \mathrm{~km}^{2}$ and an AOO of more than $14,400,000 \mathrm{~km}^{2}$.

Selected specimen: BRAZIL. SANTA CATARINA: Florianópolis, 20.XI.2010, fl, fr, Affonso et al. 110 (CRI, FLOR, FURB, K).

11. Scleria sellowiana Kunth, Enum. Pl. 2: 350. 1837. TYPE: Brazil, F. Sellow s.n. (holotype B destroyed; lectotype $\mathrm{K}$ designated here; photo of holotype F image!).

Fig. 3i-1

Perennial herbs, erect, $30-80 \mathrm{~cm}$ tall, rhizomatous. Culm 1-3 mm wide, not branching, angle smooth. Sheath 5-10 cm long, not winged; ligule absent; contraligule $0.5-1.0 \mathrm{~mm}$ long, obtuse, glabrous, membranous appendage absent; leaf blade 20-30 × 0.1-0.2 cm, linear, apex acute, margin smooth. Inflorescence a fascicle, terminal and axillary, $0.3-1.8 \times 0.5-1.5 \mathrm{~cm}, 2-4$ spikelets in each fascicle; bracts $0.5-3 \times 0.3-0.5 \mathrm{~cm}$. Spikelets androgynous or subandrogynous, sessile or pedicellate, staminate glume $2-4 \times 1-2 \mathrm{~mm}$, pistillate glume 3-4 × 1-2 mm. Achene 1-2 × 1.0$1.5 \mathrm{~mm}$, trigonous-globose, reticulate or rugose, glabrous, white, base stipitate, entire, pores absent, basal disk absent; stylobase absent. Hypogynium bearing six papillose tubercles disposed in three pairs at the base of the achene.

Scleria sellowiana is a subtropical species known from southern South America (Barros 1960) and within Brazil only recorded from the Atlantic Forest of southern Brazil (Alves et al. 2014). In Santa Catarina it is distributed along the coastal area, in the northern and southern plateaux, on wet grasslands, along the edges of streams and on sunny slopes. Sellow and Kunth, respectively the 
collector of the type of S. sellowiana and the author of the species, were based in the Berlin herbarium (B). Although Kunth (1837) did not specify where the type collection was placed, it is reasonable to believe that the holotype was placed in the Berlin herbarium (B). Stafleu \& Cowan (1981) state that Sellow's Cyperaceae type collection remains extant at B; however, a recent search was conducted for S. sellowiana type material but proved fruitless. It is therefore likely to have been destroyed. Since the K sheet is so far the only Sellow collection found bearing Kunth's handwriting, and it also provides a perfect match of the species diagnosis, it is therefore chosen as the lectotype. Scleria sellowiana resembles S. balansae Maury ex Micheli, S. ciliata Michx., S. filiculmis and $S$. georgiana ssp. australis, all of which it is often misidentified as in herbarium collections. However, diagnostic taxonomic characters are found in the achene: smooth in S. balansae and $S$. georgiana ssp. australis as opposed to reticulate or rugose in S. sellowiana. Scleria filiculmis has a disc compressing the tubercles of the hypogynium, which is lacking in S. sellowiana, while S. ciliata has sharp projections and cavities at the base of the achene, which are absent from the achene of $S$. sellowiana. The species has been collected in flower and fruit from October to January.

IUCN Red List category - LEAST CONCERN (LC). A widespread species across southern South America, including within protected areas, with an EOO of more than $4,200,000 \mathrm{~km}^{2}$ and an AOO of more than $1,500,000 \mathrm{~km}^{2}$.

Selected specimen: BRAZIL. SANTA CATARINA: Lages, 7.I.2011, fl, fr, Affonso et al. 179 (FLOR, ICN, K, MBM).

12. Scleria uleana Boeck., Allg. Bot. Z. Syst. 2: 159. 1896. TYPE: Brazil, Santa Catarina, Tubarão, E. H. G. Ule 1373 (lectotype K! designated by Camelbeke et al. 2000).

Fig. 3m-p

Perennial herb, climbing, 55-180 cm tall, rhizomatous. Culm 1-3 mm wide, not branching, angle smooth. Sheath $2.5-4.5 \mathrm{~cm}$ long, winged; ligule absent; contraligule 2-6 mm long, lanceolate, glabrous, membranous appendage absent; leaf blade $5-20 \times 0.5-0.9 \mathrm{~cm}$, linear, apex acute, margin scabrous. Inflorescence a paniculodium, lax, terminal and axillary, $3-6 \times 1.0-1.5 \mathrm{~cm}$; bracts $5-12 \times 0.2-0.5 \mathrm{~mm}$. Spikelets subandrogynous or staminate, sessile and pedicellate, respectively, staminate glume $1.5-2.0 \times 1.0-1.5 \mathrm{~mm}$, pistillate glume $2 \times 1.5-2.0 \mathrm{~mm}$. Achene $2-5 \times 1.5-2.5$ $\mathrm{mm}$, ovoid, smooth, glabrous, brown (white if imature), base stipitate, entire, pores absent, basal disk absent; stylobase deciduous. Hypogynium cupuliform, cartilaginous, margin ciliolate.

Scleria uleana is endemic to Brazil, occurring in the Atlantic Forest domain of the South and Southeast regions (Alves et al. 2014). Records from Santa Catarina report populations only in coastal areas, occurring at the edges of streams in preserved or disturbed sandbank vegetation. Flowers and fruits from April to December in Santa Catarina.

IUCN Red List category - LEAST CONCERN (LC). Although endemic to southern Brazil, this species is well distributed across that region, including within protected areas. A collection cited from Pará (northern Brazil) needs its identity confirmed. From southern Brazil alone S. uleana has an EOO over 1,700,000 $\mathrm{km}^{2}$ and an AOO of more than $580,000 \mathrm{~km}^{2}$.

Examined specimen: BRAZIL. SANTA CATARINA: Ibiraquera, 6.XII.2010, fl, fr, Affonso \& Zanin 132 (FLOR, K, NY, RB).

13. Scleria variegata (Nees) Steud., Syn. Pl. Glumac. 2: 176. 1855. Hypoporum variegatum Nees in C.F.P. von Martius, Fl. bras. 2(1): 173. 1842. TYPE: Brazil, Minas Gerais, Sebastianópolis, C. F. P. von Martius s.n. (holotype M). $\quad$ Fig. 3q-u

Perennial herbs, climbing, 120-250 cm tall, rhizomatous. Culm triangular, 1-2 mm wide, climbing, not branching, angle smooth. Sheath 5-10 cm long, not winged; ligule absent; contraligule 2-3 $\mathrm{mm}$ long, obtuse, pilose, membranous appendage absent; leaf blade 15-52 × 0.3-0.6 cm, linear, apex attenuated, margin scabrous. Inflorescence a paniculodium, fasciculate, terminal and axillary, $4.5-10.0 \times 2.5-4.0 \mathrm{~cm}$, fascicles $4-10$ disposed along the stem; bracts $6-19 \times 0.15-0.05 \mathrm{~cm}$. Spikelets subandrogynous or staminate, sessile, staminate glume 3-4 × 1-2 mm, pistillate glume 3-4 $\times 2.0-2.5 \mathrm{~mm}$. Achene 1-2 $\times 1-2 \mathrm{~mm}$, depressedglobose, verrucose, glabrous, white (rarely brown), base stipitate, entire, pores absent, basal disk absent; stylobase absent. Hypogynium absent.

Scleria variegata is endemic to southern Brazil (Core 1936; Muniz \& Shepherd 1987), occurring in the Atlantic Forest domain (Alves et al. 2014). In Santa Catarina, a single population has been found in Florianópolis, recorded in 2007 and again in 2010, at the edges of coastal forest. The species is distinguished by its climbing habit, 


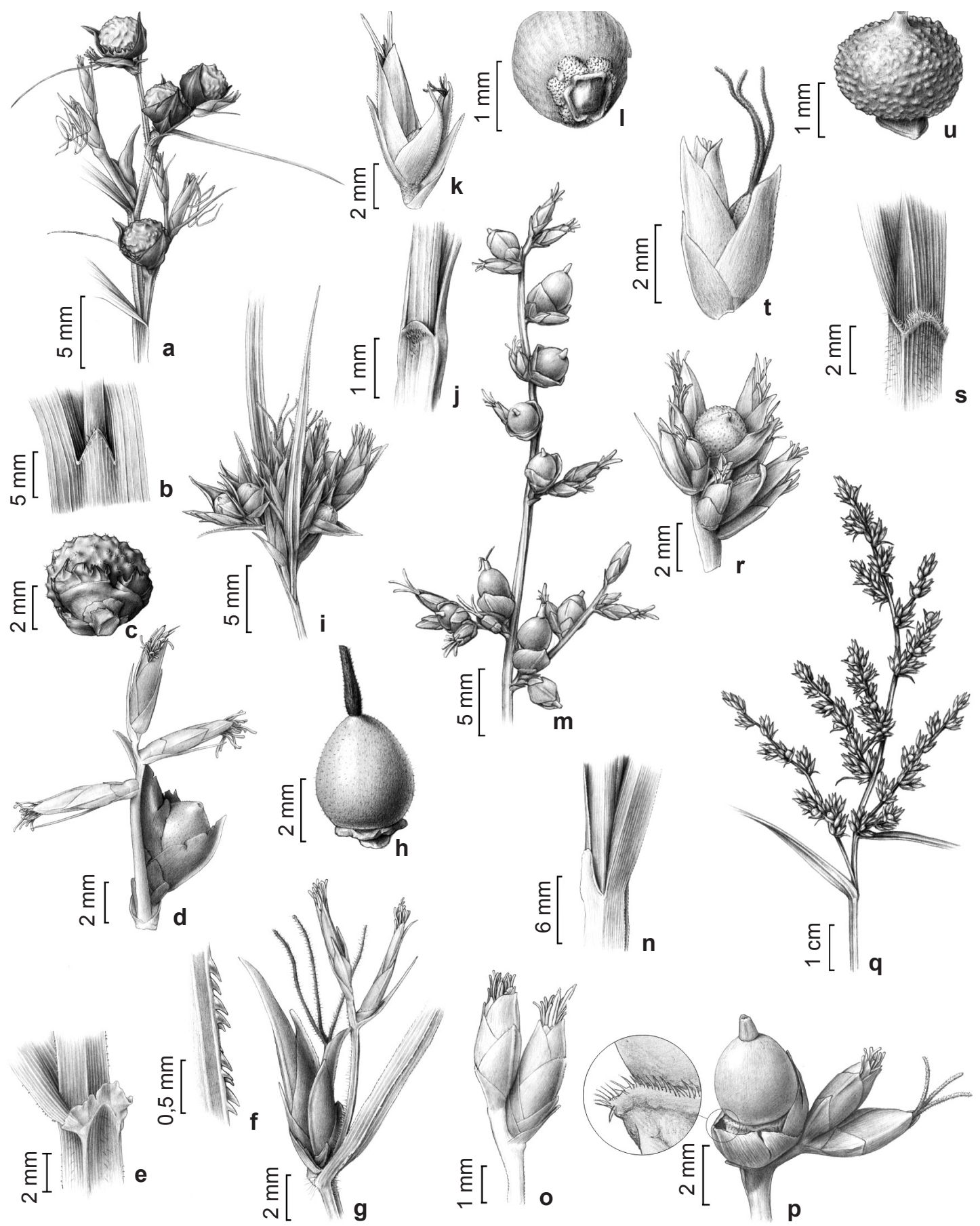

Figure 3 - a-c. Scleria plusiophylla (Siqueira 241) - a. partial inflorescence; b. contraligule triangular; c. achene rugose, hypogynium trilobed, margins fimbriate. d-h. Scleria secans (R. Affonso et al. 110) - d. partial inflorescence; e. contraligule with a membranous appendage; f. leaf margin "razor-like"; g. spikelets; h. achene bering stylobase, hypogynium trilobed, margins entire. i-1. Scleria sellowiana (R. Affonso et al. 183) - i. inflorescence; j. contraligule obtuse; k. spikelet; 1. achene reticulate, hypogynium bering tubercles. m-p. Scleria uleana (R. Affonso \& A. Zanin 132) - m. inflorescence; $\mathrm{n}$. contraligule lanceolate; o. spikelets; $\mathrm{p}$. achene bering stylobase; hypogynium cupuliform. q-u. Scleria variegata (R. Affonso et al.106) - q. inflorescence; r. partial inflorescence showing achene; s. contraligule obtuse, pilose; t. spikelet; u. achene verrucose. 
differing from $S$. secans by the absence of a ligule, and differing also from $S$. uleana in the characters of the achene and hypogynium. It flowers and fruits from August to November.

IUCN Red List category - LEAST CONCERN (LC). This species is widely distributed although uncommon within its range, yet it has been recorded from several localities, including within protected areas. It has an EOO of almost 900,000 $\mathrm{km}^{2}$ and an AOO of more than $430,000 \mathrm{~km}^{2}$. Examined specimen: BRAZIL. SANTA CATARINA: Florianópolis, 14.XI.2010, fl, fr, Affonso et al. 105 (FLOR, ICN, K, NY).

\section{Acknowledgements}

The authors acknowledge the curators of the herbaria listed, particularly the Royal Botanic Gardens, Kew, who attended the first author during her stay in London. The authors would like to thank the artist Rogerio Lupo for the illustrations.

\section{References}

Adams, C. 1994. Scleria. In: Davidse, G.; Sousa, M. \& Chater, A.O. (eds.). Flora Mesoamericana. Vol. 6. Saint Louis, Missouri Botanical Gardens Press. Pp. 476-484.

Affonso, R.; Araújo, A.C. \& Zanin, A. 2013. Lectotypifications in Scleria P. J. Bergius (Cyperaceae) from South America. Journal of the Torrey Botanical Society 140: 256-258.

Alves, M.; Araújo, A.C.; Hefler, S.M.; Trevisan, R.; Silveira, G.H. \& Luz, C.L. 2014. Cyperaceae In: Lista de Espécies da Flora do Brasil. Jardim Botânico do Rio de Janeiro. Available at <http:// floradobrasil.jbrj.gov.br/2012/FB000100>. Access on 23 November 2014.

Araújo, A.C. 2009. Scleria. In: Cavalcanti T.B. \& Batista, M.F. (eds.). Flora do Distrito Federal. Vol. 7. Brasília, Embrapa. Pp. 125-153.

Araújo, A.C.\& Brummitt, N.A. 2011. Scleria rubrostriata, a new species of Cyperaceae from the Brazilian Atlantic Forest. Kew Bulletin 66: 517-520.

Ball, P.W.; Reznicek, A.A. \& Murray, D.F. 2014. Cyperaceae In: Flora of North America 23. Available at $<\mathrm{http}$ ://www.efloras.org/florataxon.aspx $>$. Access on 15 June 2014.

Barros, M. 1960. Las Ciperaceas del Estado de Santa Catalina. Sellowia 12: 181-450.

Beentje, H. 2010. The Kew Plant Glossary. Surrey, Kew Publishing. Pp. 1-160.

Brooks T.; Tobias, J. \& Balmford, A. 1999. Deforestation and bird extinctions in the Atlantic forest. Animal Conservation 2: 211-222.

Burkart, A. 1975. Evolution of grasses and grasslands in South America. Taxon 24: 53-66.
Camelbeke, K.; Wilde, B.; Simpson, D.A. \& Goetghebeur, P. 2000. Typifications in the genus Scleria P.J. Bergius (Cyperaceae). Kew Bulletin 55: 993-996.

Camelbeke, K.; Spruyt, K. \& Goetghebeur. P. 2003. The genus Scleria (Cyperaceae) in Bolivia. Revista de la Sociedad Boliviana de Botânica 4: 139-170.

Core, E.L. 1936. The American species of Scleria. Brittonia 2: 1-105.

Ferreira, P.M.A. \& Eggers, L. 2008. Espécies de Cyperaceae do Centro de Pesquisa e Conservação da Natureza Pró-Mata, município de São Francisco de Paula, RS, Brasil. Acta Botanica Brasilica 22: 173-185.

Fonseca, G.A.B.; Mittermeier, R.A. \& Seligmann, P. 2003. Foreword. In: Leal C.G. \& Câmara, I.G. (eds.). The Atlantic Forest of South America: Biodiversity Status, Threats, and Outlook. Island Press, London. Pp. 1-3.

Goetghebeur, P. 1998. Cyperaceae. In: Kubitizki, K.; Huber, H.; Rudall, P.; Stevens, P. \& Stuzel, T. (eds.). The families and genera of vascular plants. Springer, Berlin. Pp. 141-190.

Guaglianone, E.R.; Marchesi, E.; Marticorena, C.; Araújo, A.C.; Mereles, F.; Alves, M.; Dhooge, S.; GonzálezElizondro, M.S.; Hefler, S.; López-Sepúlveda, M.G.; Trevisan, R. \& Wheeler, G. 2008. Cyperaceae. In: Zuloaga, F.O.; Morrone, O. \& Belgrano, M.J. (eds.). Catálogo de las Plantas Vasculares del Cono Sur - I: Pteridophyta, Gymnospermae, Monocotyledoneae. Vol. 1. Missouri Botanical Gardens Press (Monographs in Systematic Botany from the Missouri Botanical Garden 107), Saint Louis. Pp. 302-400.

Heywood, V.H.; Brummitt, R.K.; Culham, A. \& Seberg, O. 2007. Flowering Plant Families of the World. Kew Royal Botanic Gardens, Surrey. 424p.

IUCN. 2012. Red List Categories and Criteria: version 3.1, second edition. Prepared by the IUCN Species Survival Comission. IUCN, Gland. 38p.

IUCN. 2014. Guidelines for using the IUCN Red List Categories and Criteria. IUCN, Gland. 87p.

Kearns, D.M.; Thomas, W.W.; Tucker, G.C.; Kral, R.; Camelbecke, K.; Simpson, D.A.; Reznicek, A.A.; González-Elizondo, M.S.; Strong, M.T. \& Goetghebeur, P. 1998. Cyperaceae. In: Berry, P.E.; Holst, B.K. \& Yatskievych, K. (eds.). Flora of the Venezuelan Guayana: Caesalpiniaceae-Ericaceae 4. Missouri Botanical Garden Press, Saint Louis. Pp. 486-663.

Kunth, K.S. 1837. Enumeratio Plantarum Omnium Hucusque Cognitarum. Vol. 2. Sumtibus J.G. Cottae, Stutgardiae. 591p.

Longhi-Wagner, H.M.; Baldini, R.M. \& Araújo, A.C. 2010. Cyperaceae Raddianae: a nomenclatural and taxonomic study of the Cyperaceae published in G. Raddi's Agrostografia brasiliensis. Kew Bulletin 65: 1-13. 
Muniz, C. \& Shepherd, J. 1987. O gênero Scleria Berg. (Cyperaceae) no estado de São Paulo. Revista Brasileira de Botânica 10: 63-94.

Myers N.; Mittermeier, R.A.; Mittermeier, C.G.; Fonseca, G.A.B. \& Kent, J. 2000. Biodiversity hotspots for conservation priorities. Nature 403: 853-858.

Raynal, J. 1976. Notes Cyperologiques: 27. Identification de deux Scleria de Poiret. Adansonia 16: 214.

Stafleu, F.A. \& Cowan, R.S. 1981. Taxonomic Literature, TL2 online. Available at <http://www.sil.si.edu/ digitalcollections/tl-2>. Access on 3 November 2014.

Strong, M.T. 1994. Two New Species of Scleria Section Scleria (Cyperaceae) from the Neotropics. Novon 4: 296-302.

Strong, M.T. 2007. Scleria tropicalis (Cyperaceae), a new species from Northern Andean South America. Harvard Papers in Botany 11: 199-201.
Strong, M.T. \& Acevedo-Rodriguez, P. 2005. Cyperaceae. In: Acevedo-Rodriguez, P. \& Strong, M.T. (eds.). Monocotyledons and Gymnosperms of Puerto Rico and the Virgin Islands. Vol. 52. Smithsonian Institution Press, Washington D.C. Pp. 236-383.

Thiers, B. [continuously updated]. Index Herbariorum: a global directory of public herbaria and associated staff. New York Botanical Garden's Virtual Herbarium. Available at $<\mathrm{http}$ //sweetgum.nybg.org/ih>. Access on 25 June 2012.

WCSP 2014. [continuously updated]. World Checklist of Cyperaceae. Kew Royal Botanic Gardens. Available at $<$ http://Apps.Kew.Org/Wcsp/>. Access on 6 May 2014.

Willis, F.; Moat, J. \& Paton, A. 2003. Defining a role for herbarium data in Red List assessments: a case study of Plectranthus from eastern and southern tropical Africa. Biodiversity and Conservation 12: 1537-1552.

\section{List of exsiccatae}

Acevedo-Rodriquez 1618 NY(10); Affonso et al. 108 FLOR, FURB, K, P(1), 111 FLOR(1), 151 FLOR, K(1), 173 FLOR, K, RB(1), 185 FLOR, K, NY, P(1), 62 FLOR, SI(3), 93 FLOR, GUA, K, NY(3), 94 FLOR(3), 112 FLOR, K(3), 56 FLOR, SP(5), 59, 60, 65, 69, 81, 96 FLOR(5), 66 FLOR, GUA, RB(5), 75 FLOR, HUEFS, K(5), 77, 113, 184 FLOR, K(5), 95 FLOR, ICN, MBM(5), 109 FLOR, K, PACA(5), 182 FLOR, ICN, K, PACA(6), 64 FLOR, K(8), 153 FLOR(9), 70 FLOR(10), 104 FLOR, GUA, K, MBM(10), 110 CRI, FLOR, FURB, K(10), 107 FLOR, K(11), 169 FLOR, ICN, K(11), 174 COL, FLOR, K, SP(11), 179 FLOR, ICN, K, MBM(11), 180 FLOR(11), 181 FLOR, K, RB(11), 183 BM, CRI, FLOR, FURB(11), 105 FLOR, ICN, K, NY(13), 106 FLOR, K, RB(13); Affonso \& Zanin 44, 45, 101, 127, 133, 137 FLOR(1), 53, 203, 206, 207, 208 FLOR, K(1), 117 FLOR, ICN, K, NY(1), 118 FLOR, FURB, K, MBM(1), 126 FLOR, K, RB, NY(1), 129 CRI, FLOR, K(1), 131 FLOR, GUA, K(1), 134, 138, 192 BM, FLOR, K(1), 189 FLOR, FURB, K(1), 197 FLOR, K, PACA(1), 200 FLOR, K, RB, ICN(1), 1 FLOR(3), 42 FLOR, K, MBM(3), 46 CRI, FLOR, GUA(3), 47, 187 FLOR, ICN, K(3), 97 FLOR, NY(3), 188 CRI, FLOR, K(3), 190 FLOR, K(3), 194 FLOR, K, PACA(3), 196 FLOR, HUEFS(3), 198 FLOR, FURB, K(3), 199 FLOR, K, MO(3), 43, 122, 130, 191 FLOR, K(5), 54 FLOR, FURB(5), 49, 51, 52, 55, 96, 121,128, 202 FLOR(5), 67 FLOR, K, MO(5), 68 FLOR, K, P(5), 98 CRI, FLOR, FURB(5), 99 BM, FLOR(5), 123 FLOR, SI(5), 124 COL, FLOR(5), 136 FLOR, HB(5), 144 FLOR, RB(9), 145, 153 FLOR(9), 146 CRI, FLOR(9), 193 BM, FLOR, K(5), 204 FLOR, K, GUA(8), 205 CRI, FLOR, ICN, K(8), 100 GUA, FLOR, ICN, K(10), 125, 195 FLOR(10), 48, 201 FLOR, K(10), 119 FLOR, FURB, ICN, K(12), 120 FLOR(12), 132 FLOR, K, NY, RB(12); Alston-Lutz $200 \mathrm{BM}(8)$; Alves $1868 \mathrm{NY}(1), 1871$ NY(3); Anchieta $704 \mathrm{HBR}(8), 703$ HBR(10); Anderson 10706 K(3), 10907 NY(7), 10600 K(7), 9655 MO(7); Andrade 153 K(5); Araújo 313 RB(10); Araújo 301, 319,327 HBR(1), 271 $\operatorname{HBR}(7), 219,300,322 \mathrm{HBR}(5), 213,218,271 \mathrm{HBR}(8), 210,302 \mathrm{HBR}(10), 1687 \mathrm{ICN}(5), 778 \mathrm{ICN}(13) ;$ Araújo \& Brummitt 1779 ICN(8), 1778 ICN (13); Araújo $746 \mathrm{MO}(1)$; Araújo $8306 \mathrm{MO}(10)$; Archer 7782 K(3); Atha $1198 \mathrm{MO}(5)$; Athayde $117 \mathrm{MBM}(3)$; Axelrod $11208 \mathrm{MO}(1)$; Bächtold et al. $14 \mathrm{JOI}(5) ;$ Baker 151 BM, K(7); Balansa 448 K(1); Bartlet 17454 NY(7); Barros s.n. HBR 18904(6), Belém 1145 NY(7); Berger 323 JOI(1), 709 MBM(5); Braga et al. 2307 RB(5); Burch $5852 \mathrm{MO}(5)$; Bürchell 8272 K(1); Burger s.n. RB 168370(3); Burman 646 NY(6); Callejas 7055 MO(1), 4962 K(7); Casari 208 NY(5); Cid 4189 K(7); Claussen 247, 248 BM(1); Clayton 4142 K(3), 4859 K(6), 4755 K(7); Conrad 2954 MO(1), 2171 MO(10), 2771(11); Cook 105 K(3); Conrad 1634 MBM(2); Cornejo $3035 \mathrm{MO}(5)$; Costa $306 \mathrm{~K}(3)$; Crow $7468 \mathrm{MO}(11)$; Custódio $2743 \mathrm{~K}(8)$; Dahlgren $72 \mathrm{NY}(3)$; Damazio s.n. RB 63615(1); Davidse et al. 17749 MO(1), 2331, 2466, 3021 MO(5), 36623 MO(7), 2224 MO(11); Deginani 1268 MO(8); Dombrowski 741,2246 K(1), 2512 K(3), 5591 FLOR(1); Duarte 7755 RB(6); Dupré s.n. NY 661306(3); Dusèn K 2622(1), 13490 BM(1); Duss 3825 MO(10); Dwyer $10046 \mathrm{MO}(4)$; Eden $30 \mathrm{~K}(3)$; Egea 343 BM(3); Ekman $17252 \mathrm{~K}(4), 1309$ NY(6); Eugênio $330 \mathrm{RB}(5)$; Falkenberg 3532 FLOR(5), 6620 FLOR(9); Felix 6649 RB(5); Fiebrig 4841 K(1), 418 K(3); Filgueiras 2151 MO(6); Foreno 7953 K(5); Fonseca 748 K(3), 254 K(6); Forzza 4308 RB(5); Fox 346 K(5); Frazão s.n. RB 11619(1); Gardner s.n. K 000189729(3), 9066 K(7), s.n. BM 000598741, s.n. K 000598741(6); Gasper 396 FURB(5), s.n. ICN 160672(8), 2050, 2154 FURB(8), 2135 FURB(9); Gentle 6748 MO(1), 8325 MO(7), 912, $6831 \mathrm{MO}(10)$; Gentry $21295 \mathrm{MO}(11)$; Geraldino $111 \mathrm{MBM}(5)$; Gifford $77 \mathrm{NY}(6)$; Glaziou $14373 \mathrm{~K}(3), 13690$ K(5), 20052 K(6); 
Gleason 472 K(7); Goeldi s.n. NY 120113(3), 1080 BM(3); Goméz 23405 MO(5); Gorinsky s.n. K 000002616(1); Goudman s.n. K $189729(3)$; Granville 6500 K(5); Guaglianone 2818 MO(8), $2999 \mathrm{SI}(8) ;$ Guillen \& Killen $2765 \mathrm{MO}(1)$; Guimarães \& Falkenberg 510 FLOR(1); Haase $895 \mathrm{~K}(7)$; Hans $263 \mathrm{RB}(1)$; Harley $17846 \mathrm{NY(5),} 10636 \mathrm{NY(6);} \mathrm{Harrison} 782 \mathrm{~K}(3)$; Hassler $1315 \mathrm{~K}, 3575 \mathrm{~K}$, s.n. K 000002660, s.n. K $000002661(1), 491$ K(3), 11302 K(5), 8081 K(7), s.n. K000524309(9); Hatschbach 3692, 15068 MBM(1), 73834, 78034, $79633 \mathrm{MBM}(5), 26041 \mathrm{~K}, \mathrm{RB}(6), 25313,33663,40508 \mathrm{MBM}(7), 26041 \mathrm{MO}(7), 14538 \mathrm{MBM}(8), 14772,15712,32959,67494$ MBM(11), s.n. MBM 26913(11), 15188, 22879 MBM(12), 24072, s.n MBM 26919, s.n. MBM 26765(13); Heringer et al. 7954 RB(5), $63050 \mathrm{~K}(6)$; Herter $611 \mathrm{MO}(11)$; Hill $12758 \mathrm{~K}(7)$; Hoehne $4068 \mathrm{~K}(5), 4069 \mathrm{~K}(8)$; Hunt $5791 \mathrm{~K}(6)$; Imaguire s.n. MBM 26720(8); Irwin et al. s.n. K 2640(1), $21108 \mathrm{~K}(3)$, s.n. RB 121258(3), $8693 \mathrm{~K}(5), 8693 \mathrm{NY(5),} 11690 \mathrm{~K}(6)$, s.n. RB 147288(6), 11690 MO(6), $25930 \mathrm{MO}(7), 11940,20768 \mathrm{MO}(10)$; Jangoux $373 \mathrm{NY}(7)$; Janssen $341 \mathrm{MO}(1)$; Jansen-Jacobs $4073 \mathrm{~K}(1)$, 429, 979, 6279(3); Jarenkow 3758 MBM(5), 1766 FLOR(5), 1823 MBM(10); Jenman 7989 K(5); Johnston 841 NY(7); Jörgensen 3588 K, MO(1); Sagot 626 K(5); Keel 337 K(7); Kiedel 912 K(5); Killen 2041 MO(6); Klein 744 HBR(1), 1642 HBR(5), 6066 FLOR(5), 1287 HBR(7), 3716(11); Klein \& Bresolin 2545 HBR(1), 6508, 6547 FLOR(1), 6180, 6550 FLOR(4); Korte 1817, 2630, 3546, 3657, 4032 FURB(8), 61, 775, 1085, 1376, 1679, 3015, 3706 FURB(9); Kuhlmann 553 RB(1); Kuniyoshi 1280 MBM(3); Kral 71797 K(7); Krug s.n. NY 109183(1); Landrum 2476 MBM(10); Lanna Sobr. \& Castellanos 861 K(3), 1845 K(5), 399 K(7); Lanjown et al. 1674, 1689, 1690 K(1), 1374 K(3), 270 RB(3); Leandro s.n. FURB 1124(5); Leite s.n. JOI 4411(3); Lindeman 3835 K(1), 4482 K(7); Lleras 16647 MO(10); Löfgren s.n. RB 4192(1), 9232 NY(5); LonghI/Wagner 8981 MBM(1); Lowe 4091, 4173, 4298 K(3), 4221 K(7); Luetzelburg s.n. NY 636745(3); Lundell $6114 \mathrm{MO}(7), 569 \mathrm{MO}(10) ;$ Mafra s.n. FURB 3133(8); Maldonado $2641 \mathrm{MO}(8) ;$ Marchett $7 \mathrm{MBM}(5) ;$ Marin s.n. BM 590230(10); Markgraf s.n. NY 612537(10); Martius s.n. K 000567333(3); Martinelli 10950 RB(5); McDaniel 8929 MO(4); McLean 13 BM(5); Mejía $6667 \mathrm{MO}(7), 11127 \mathrm{MO}(10) ;$ Mello 593 FLOR(5); Melo 228 K(5); Meruvia 14 FLOR(3); Mexia 4970 K(7), 4686 BM(8); Miers 3855 K(1); Mimura 269 K(1); Mondragon 137 MO(5); Monte 3077 MO(7); Montes 3291 K(1), 15255 MO(11); Moore 836 NY(7); Morales $2963 \mathrm{MO}(11) ;$ Morong $424 \mathrm{~K}(1) ;$ Mori s.n. RB 409246(7); Morrone et al. $2129 \mathrm{MO}(5), 1633 \mathrm{SI}(8), 1628 \mathrm{MO}(10) ;$ Morton et al. $3428 \mathrm{MO}(10)$; Muniz $242 \mathrm{NY}(8)$; Nee $0951 \mathrm{MO}(7)$; Negrelle 310, 411 CRI(5), $262 \mathrm{CRI}(9)$; Oliveira $232 \mathrm{~K}(6)$; Orth 1035 MO(1), 704 K(8); Pasini 240 MBM(1); Passold s.n. FURB 3640(5); Pedersen 7985 K, s.n. K000002653(1), 7548 K(3), 5968 K(5), 18812 MO(11); Pereira 269 K(1), 3921 RB(5); Perón 872 NY(8); Phibeax 3696 K(1); Philcox 4020 K(3), 3335 MO(10); Pirani et al. CFSC6922 K(1); Plowman 8876 MO(10); Poiteau s.n. K 000584486(7); Poliquese 145 MBM(8); Prance et al. 14105 K (3), 3999 K(7); Preston 1872 K(8); Quarín 1068 RB(3); Queiroz s.n. FLOR 113, 135, 319, 31604a(1), 162, 361, 31495 FLOR(3), 75, 552 FLOR(5), s.n. FLOR 29584, $31611 a(5), 274$ FLOR(8), s.n. FLOR 29582(8), 77, 332 FLOR(10), s.n. FLOR 29557(11); Rabello 197 K(1); Rambo s.n. RB 53814(1), 44233, $46126 \mathrm{~K}(5), 57060 \mathrm{HBR}(5), 37920 \mathrm{MO}(5), 44237,54528 \mathrm{HBR}(11)$; Ratter $3593 \mathrm{~K}(5), 1034 \mathrm{~K}(6), 1034 \mathrm{NY}(6), 6364$ NY(10); Regnel 1321 NY(6); Reitz 1585, 4975, 5338, 5537 HBR(1), 17897 FLOR(1), 6725, 6764 PACA(1), 1054 PACA(4), 6761 PACA(5), 1869, 1916 HBR(8), 533, 570, 8912, 10960(9), 2269, 3794(10); Reitz \& Bresolin 1217 PACA(4); Reitz \& Klein 399, 5152, 5668, 8424, 10304, $10934 \mathrm{HBR}(1), 17825 \mathrm{MBM}(1), 10067 \mathrm{HBR}(2), 855,1028,6790$, (5), 10864, 11983(6), 1796, 10461(8), 6789(9), 210, 2292, 2643, 3794, $9191 \mathrm{HBR}(10), 3794,6700 \mathrm{PACA}(10), 5139 \mathrm{HBR}(10)$; Richter $144 \mathrm{JOI}(1), 55(10)$; Riedel $911 \mathrm{BM}(1), 909$ $\mathrm{BM}(3), 912 \mathrm{BM}(5), 158 \mathrm{~K}(6), 2990 \mathrm{BM}(6)$; Rimachi 4564 RB(7); Rinnert $485 \mathrm{JOI}(3) ;$ Ritter $1402 \mathrm{MO}(7)$; Rocha 3 CRI(9); Rondon s.n. RB 54495, 54496(1); Rosales $2245 \mathrm{MO}(11)$; Roubik $102 \mathrm{MO}(1)$; Saint-Hilaire 95, 1686 P(1), s.n. P 274497(1), 537(3), $135(5)$, 1747 P(9), 38 P(10); Saltzmann s.n. K $000189731(3)$, s.n. K $000584485(7) ;$ Santos 108 CRI(5); Sarmento 727 RB(5); Schomburk 660 K(7); Secco 196 K(7); Sellow s.n. K $000189712(1)$, s.n. K 000567331 (3), s.n. [40 on sheeat] BM (3), 719 MO(8); Sevegnani s.n. FURB $3717(5)$; Shafer $11025 \mathrm{MO}(4)$; Silva $97 \mathrm{MBM}(8)$; Silva et al. 1856 K(7); Silva $658 \mathrm{MO}(1)$; Silva et al. 98, 977 FLOR(5); Silva 3270 MBM(1); Silva 125 K(5); Silva \& Bahia 2988 RB(5); Silveira 171, 215, 249, 264 ICN(1); Siqueira 241 FLOR(9); Skvortzov 172 K(1); Smith 7518, 9391, 13309, 13774 HBR(1), s.n. K 000002642(1), 7977 HBR(10); Smith Klein 10991 HBR(6), 7572(10), 7333, 7458, 8558 HBR(11); Sobel et al. s.n. K 2633(1); Sobral 8340 MBM(1), s.n. FURB 2502(1), 5214 MBM(5), 82 MBM(8), 4787 MBM(11); Soeprato 256 K(3); Sohwacke 60 RB(1); Solomon 10818 RB(5); Souza \& Falkenberg 392 ICN(1), 322 FLOR(5); Sperling 5861 K(5); Spruce s.n. K 000002621(1), s.n. K 000567334(3); Steinbach 6861 BM(1), 5300 NY(6); Stijfhoorn 755 MO(5); Stival-Santos 3000 FURB(9), 1707 FURB(10); Stoffers 210 K(3); Sucre 2024 NY(3), 9005 RB(3), 3595, 9509 RB(5), s.n. RB 165570(5), 4113 K(5); Svollenski 377 MBM(13); Tamandaré 278 RB(1); Tavares \& Guimarães s.n. FLOR 38973(4); Taylor 11665 MO(11); Tessmann s.n. MBM 75852(5), s.n. MBM 75904(10); Thomas $11556 \mathrm{MO}(5), 12629 \mathrm{MO}(8), 12431,12558 \mathrm{MO}(10) ;$ Trail s.n. K s.n.(7); Trevisan 454, 593, $715 \mathrm{ICN}(1), 576,758 \mathrm{ICN}(3), 648 \mathrm{ICN}(5), 646 \mathrm{ICN}(9)$; Türckheim s.n. K 2627(1); Tye $35 \mathrm{~K}(7)$; Ule $1939 \mathrm{~K}(2), 1923 \mathrm{~K}(6), 5298$ K s.n.(7), 1371 K(12); Valério $127 \mathrm{MO}(1)$; Vargas $1579 \mathrm{MO}(5)$; Vasquez $21136 \mathrm{MO}(5)$; Véliz $98623 \mathrm{MO}(5)$; Verdi et al. 1773, 4468, 5087 FURB(5), 116, 2525, 4770, 4997 FURB(8), 2239, 4633 FURB(9), 2674 FURB(10); Vieira 355 RB(3); Vieira 920, 1246 JOI(5), $1042 \mathrm{JOI}(8)$; Whitefoord $2403 \mathrm{MO}(1), 2356 \mathrm{MO}(7), 1262 \mathrm{MO}(10)$; Woitexem $61 \mathrm{JOI}(10)$; Woolston 577, $1427 \mathrm{~K}(1), 463 \mathrm{~K}(3)$; Wright 2165 K(4), 724 MO(7); Yamanaka 4 FLOR(5); Zanette 2416 CRI(5), 547, 905, 2478 CRI(8), 2478 CRI(9); Zanin 1119 ICN(1), 1623 FLOR(3); 1622 FLOR(10); Zappi et al. 1088 K(7); Zardini et al. 16867 BM(3), 50986 MO(5), 55068 MO(8); Zika 12245 K(7); Zocche s.n. CRI 8661(8); Zuloaga $3929 \mathrm{MO}(5)$. 